\title{
ОБАВЕШТЕЊЕ РЕДАКЦИЈЕ
}

У Гласнику $A K B$ за јануар 2015. године објављен је чланак СТИЦАњЕ СВОЈИНЕ ОД НЕВЛАСНИКА, аутора Данијела Волара. На захтев аутора, обавештавамо читаоце да је текст опремљен фуснотама, иако је објављен без њих.

Редакција напомиње да је текст примила без фуснота, тако да није реч о пропусту у приређивању.

У сваком случају, жао нам је што текст није објављен у интегралној верзији. 